\title{
APLIKASI TEKNOLOGI COMPLETE FEED DAN SILASE PADA PETERNAK KAMBING DI DESA SIDOREJO KECAMATAN SEKAMPUNG UDIK KABUPATEN LAMPUNG TIMUR
}

\section{APPLICATION OF COMPLETE FEED AND SILAGE TECHNOLOGY ON GOAT FARMERSS IN THE VILLAGE OF SIDOREJO, SEKAMPUNG UDIK DISTRICT OF LAMPUNG TIMUR}

\author{
N Fajrih 1a, A F Fanani1 , M Khoiruddin ${ }^{1}$ \\ ${ }^{1}$ Fakultas Pertanian Perikanan dan perternakan, Universitas Nahdlatul Ulama lampung \\ ${ }^{a}$ Korespondensi: Nurul Fajrih H; E-mail: nunu.nurul1919@gmail.com \\ (Diterima: 30-09-2019; Ditelaah: 01-09-2019; Disetujui: 14-09-2020)
}

\begin{abstract}
The Sidorejo village has a goat farmers group active and productive namely the "Krida Muda" livestock group which was established since in 2016. This community of PKM Partners. Various problem faced by partners will be offered a solution in this PKM activity. Scarcity of feed during the dry session is a common problem faced by partner farmers. In addition, there is still a lack of technological insight in partner groups in utilizing agricultural waste into animal feed. The implementation of PKM performed with several method among others with counseling for material that is theoretical, demonstration to deliver practice material and direct accompany during demonstration or practices. The results obtained are PKM partner farmerss increase their knowledge and insight on the technology of complete feed, silage and able to process of agricultural waste (cassava crop waste and corn crop waste) to be quality feed and can be stored to overcome the scarcity of feed in dry season.
\end{abstract}

Keywords : Agriculture waste, complete feed, goat farmers, silage.

\begin{abstract}
ABSTRAK
Desa Sidorejo mempunyai Kelompok Peternak kambing yang aktif dan produktif yaitu kelompok ternak "Krida Muda" yang berdiri sejak tahun 2016. Kelompok peternak inilah yang dijadikan Mitra PKM. Berbagai permasalahan yang dihadapi mitra akan ditawarkan solusinya dalam kegiatan PKM ini. Kelangkaan pakan saat musim kemarau menjadi permasalahan umum yang dihadapi peternak mitra. Selain itu masih kurangnya wawasan teknologi kelompok mitra dalam memanfaatkan limbah hasil pertanian menjadi pakan ternak. Pelaksanaan PKM dilakukan dengan beberapa metode antara lain dengan ceramah/penyuluhan untuk materi yang bersifat teori, peragaan untuk menyampaikan materi praktek dan pendampingan langsung saat demonstrasi atau praktek. Hasil yang diperoleh yaitu peternak mitra PKM bertambah pengetahuan dan wawasannya tentang teknologi pembuatan complete feed, silase dan mampu mengolah limbah pertanian (limbah tanaman singkong dan limbah tanaman jagung) menjadi pakan yang berkualitas serta dapat disimpan untuk mengatasi kelangkaan pakan pada musim kemarau.
\end{abstract}

Kata Kunci : Peternak kambing, limbah pertanian, complete feed, silase. 
Fajrih, N., Fanani, A. F., \& Khoiruddin, M. (2020). Aplikasi Teknologi Complete Feed dan Silase Pada Peternak Kambing di Desa Sidorejo Kecamatan Sekampung Kabupaten Lampung timur. Jurnal Qardhul Hasan : Media Pengabdian kepada Masyarakat, 6(2), 107-113.

\section{PENDAHULUAN}

Desa Sidorejo Terletak di Kecamatan Sekampung Udik Kabupaten Lampung Timur, Propinsi Lampung yang memiliki luas wilayah 142.997 hektar. Desa Sidorejo terdiri dari 11.406 jiwa dengan jumlah penduduk laki-laki 5.853 atau sebesar 51,3 persen dan 5.553 jiwa penduduk perempuan atau sebesar 48,7 persen. Mata pencaharian terdiri dari berbagai macam pekerjaan, namun yang paling dominan adalah sebagai petani dan peternak selebihnya adalah pedagang, swasta, pegawai negeri dan lain-lain. Hasil pertanian dan perkebunan masyarakat berupa tanaman padi, singkong, ubi jalar, jagung, pisang, kacang tanah dan sayursayuran.

Desa Sidorejo mempunyai Kelompok Peternak kambing yang aktif dan produktif yaitu kelompok ternak "Krida Muda" yang berdiri sejak 2016. Kelompok peternak inilah yang menjadi Mitra PKM. Jumlah anggota Kelompok Ternak Krida Muda sebanyak 35 orang dengan populasi ternak kambing sebayak 150 ekor. Kendala pengembangan peternakan di wilayah Mitra yaitu rendahnya pengetahuan para peternak mengenai teknologi pakan serta penanganan limbah kotoran kambing. Saat ini pemberian pakan kambing di kelompok mitra menggunakan cara tradisional yaitu mengandalkan mencari rumput atau biasa disebut ngarit setiap hari dengan pemberian hijauan rumput lapangan pada musim penghujan dan melakukan pengawetan daun singkong sebagai cadangan makanan saat musim kemarau. Sementara limbah dari kotoran kambing belum dimanfaatkan lebih jauh.

Berdasarkan hasil pengamatan langsung diketahui bahwa pertumbuhan kambing pada kelompok ternak mitra tersebut masih rendah, dengan pemberian hijauan rumput lapangan pada musim penghujan sedangkan diberikan silase daun singkong pada musim kemarau, sehingga kebutuhan nutrisi ternak kambing tidak mencukupi dan pada akhirnya berpengaruh terhadap produktivitasnya. Sebagaimana diketahui bahwa pakan merupakan biaya produksi yang terbesar dalam usaha peternakan yaitu sekitar 60 - 80\% dari biaya produksi (Hardianto et al, 2002). Oleh karena itu, penyusunan ransum tidak hanya harus mencukupi kebutuhan nutrisi saja tetapi juga harus menguntungkan secara ekonomis.

Berdasarkan hasil wawancara, kelompok mitra juga belum menggunakan pakan tambahan seperti konsentrat untuk memenuhi kebutuhan ternaknya. Padahal pemberian konsentrat sebagai pakan tambahan akan sangat mempengaruhi produktivitas ternak. Konsentrat merupakan campuan bahan pakan untuk meningkatkan keserasian gizi dimaksudkan untuk disatukan (Hartadi et al., 1991).

Permasalahan limbah tanaman jagung, padi maupun singkong hingga saat ini belum ada yang menangani, sehingga untuk mengatasi masalah tersebut perlu diperkenalkan sentuhan teknologi untuk mengolah dan mengawetkan limbah tersebut menjadi pakan yang bergizi tinggi dan tentunya dapat meningkatkan penyediaan pakan ternak secara kontinyu. Melalui aplikasi teknologi complete feed dan silase, maka pemanfaatan limbah pertanian yang melimpah di daerah mitra dapat diubah menjadi produk daging yang bernilai jual tinggi. Complete feed merupakan metode pemberian pakan dengan mencampurkan hijauan dan konsentrat secara homogen serta mencegah ternak menseleksi pakan (Thiasari dan Setiawan, 2016). Pemberian pakan dalam bentuk complete feed dapat meningkatkan konsumsi pakan dan pertambahan bobot badan harian sapi potong (Nusi et al., 2011). Sedangkan Silase merupakan salah satu 
bentuk pengawetan hijauan pakan. Prinsip pembuatan silase adalah menghentikan kontak hijauan dengan oksigen, sehingga dalam keadaan anaerob bakteri asam laktat dapat tumbuh dengan mengubah karbohidrat mudah larut menjadi asam laktat (Heinritz, 2011).

Program Kemitraan Masyarakat ini bertujuan untuk memberikan pengetahuan, keterampilan, pelatihan dan pendampingan kepada masyarakat dalam mengolah limbah hasil pertanian yaitu jagung dan singkong menjadi produk pakan berkualitas dan dapat disimpan untuk mengatasi kelangkaan pakan musim kemarau.

\section{MATERI DAN METODE}

Kegiatan PKM ini menggunakan beberapa metode yaitu sebagai berikut : Metode penyuluhan atau ceramah melalui penyampaian informasi yang berkaitan langsung dengan pencapaian luaran kepada anggota mitra kelompok ternak Krida Muda. Informasi tersebut berbentuk materi penyuluhan, disampaikan baik secara lisan maupun tulisan oleh tim pelaksana PKM maupun narasumber terkait.

Metode diskusi melalui penyampaian pertanyaan kepada tim pelaksana PKM utamanya yang berkaitan dengan masalah anggota kelompok mitra ataupun terhadap isi materi penyuluhan yang belum dapat dipahami dengan baik.

Metode Demonstrasi melalui pemberian contoh dan kesempatan kepada anggota mitra kelompok untuk mengetahui dan memahami berbagai proses adopsi ilmu pengetahuan teknologi yang diberikan dalam kegiatan PKM.

Metode pendampingan, monitoring dan evaluasi pelaksanaan kegiatan yang dilakukan tim pelaksana kegiatan PKM kepada anggota kelompok mitra.

\section{Prosedur Kegiatan}

Prosedur kegiatan Pelaksanaan PKM yaitu sebagai berikut :

\section{Metode ceramah}

Pertemuan dan sosialisasi oleh tim pelaksana PKM kepada anggota mitra kelompok ternak kambing Krida Muda menyangkut rencana kegiatan PKM.

Pertemuan tim pelaksana PKM untuk menyiapkan narasumber dan materi-materi penyuluhan terkait. Pemberian materi penyuluhan kepada anggota mitra kelompok Krida Muda meliputi : Pengenalan jenis-jenis kambing penghasil daging di Indonesia dan Luar Negeri sesuai standar pasar dan potensinya untuk dikembangkanTeknologi complete feed (pakan komplit) Silase komplit.

\section{Metode diskusi}

Anggota mitra kelompok ternak Krida Muda mengajukan pertanyaan misalnya tentang masalah yang berkaitan dengan materi penyuluhan. Tim pelaksana PKM maupun narasumber memberikan tanggapan dalam bentuk jawaban atas pertanyaan ataupun solusi terhadap permasalahan yang dihadapi anggota mitra kelompok sekaligus memberikan dukungan atau motivasi terhadap perilaku positif yang mendukung pengembangan aktivitas usaha mitra kelompok ternak tersebut.

\section{Metode demonstrasi}

Persiapan alat (copper, mixer pakan, timbangan, bak, platik, silo) dan bahan (limbah pertanian dan perkebunan, bahan penyusun pakan tambahan seperti onggok, bungkil sawit, bungkil kedelai, bungkil kopra, CGF, dedak padi, kulit kopi, molases, mineral mix, garam, urea dan strater bakteri) oleh tim pelaksana PKM maupun anggota mitra kelompok ternak Krida Muda. Penjelasan singkat prosedur kerja oleh tim pelaksana PKM maupun narasumber terkait. Anggota mitra kelompok ternak Krida Muda melakukan aktivitas demonstrasi sesuai bimbingan tim pelaksana PKM atau narasumber. 


\section{Metode pendampingan, monitoring dan evaluasi}

Penyusunan jadwal pendampingan dan monitoring aktivitas kegiatan PKM oleh tim pelaksana. Pemantauan dan bimbingan teknis terkait pengetahuan dan teknologi yang diperkenalkan dalam kegiatan PKM. Evaluasi pelaksanaan demonstrasi untuk mengetahui tingkat penerimaan anggota mitra kelompok tani Krida Muda terhadap ilmu pengetahuan dan teknologi yang diberikan. Evaluasi permasalahan dan kendala selama pelaksanaan kegiatan PKM disertai pemberian solusi.

\section{HASIL DAN PEMBAHASAN}

Hasil dari kegiatan pengabdian kepada masyarakat mengenai PKM Kelompok Peternak Kambing Melalui Aplikasi Teknologi Complete Feed dan Silase di Desa Sidorejo Kecamatan Sekampung Udik yaitu antara lain yaitu jumlah peserta pelatihan mencapai $85 \%$ dari jumlah peserta yang ditargetkan, hal ini menunjukkan minat yang tinggi dari para peserta untuk mendapatkan pengetahuan yang baru dalam pemanfaatan limbah pertanian menjadi produk pakan ternak. Adapun rincian hasil kegiatan penyuluhan yaitu sebagai berikut : Sebelum mengawali kegiatan pengabdian ini, kami melakukan kegiatan pretest terlebih dahulu dengan tujuan untuk mengetahui informasi mengenai pemahaman peternak mitra sebelum dilakukan kegiatan penyuluhan maupun pelatihan/demonstrasi. Informasi yang diperoleh dari hasil pretest selanjutnya digunakan sebagai dasar pelaksanaan kegiatan selanjutnya. Hasil Pretest disajikan pada table 1 sebagai berikut :

Tabel 1. Hasil Pretest

\begin{tabular}{|l|l|l|}
\hline Pertanyaan & Ya & Tidak \\
\hline $\begin{array}{l}\text { Mengetahui tentang jenis } \\
\text { ternak kambing pedaging } \\
\text { dan penghasil susu di }\end{array}$ & & $65 \%$ \\
$\begin{array}{l}\text { Indonesia? } \\
\begin{array}{l}\text { Mengetahui menejemen yang } \\
\text { baik dalam memelihara }\end{array}\end{array}$ & & \\
\hline
\end{tabular}

\begin{tabular}{|l|l|l|}
\hline kambing? & & \\
\hline $\begin{array}{l}\text { Mengetahui tentang tanda- } \\
\text { tanda ternak birahi/estrus? }\end{array}$ & $7 \%$ & $93 \%$ \\
\hline $\begin{array}{l}\text { Mengetahui tentang } \\
\text { penanganan/pemeliharaan } \\
\text { anak kambing yang } \\
\text { berjumlah lebih dari 2 ekor? }\end{array}$ & $0 \%$ & $100 \%$ \\
\hline $\begin{array}{l}\text { Mengetahui tentang } \\
\text { pengolahan limbah tanaman } \\
\text { singkong dan limbah } \\
\text { tanaman jagung menjadi } \\
\text { pakan bergizi? }\end{array}$ & $10 \%$ & $90 \%$ \\
\hline $\begin{array}{l}\text { Mengetahui teet dan } \\
\text { teknologi complete feed } \\
\text { silase? }\end{array}$ & & \\
\hline $\begin{array}{l}\text { Mengetahui tentang cara } \\
\text { pembuatan complete feed? }\end{array}$ & $0 \%$ & $100 \%$ \\
\hline $\begin{array}{l}\text { Mengetahui tentang cara } \\
\text { membuat silase? }\end{array}$ & $5 \%$ & $95 \%$ \\
\hline $\begin{array}{l}\text { Mengetahui tentang manfaat } \\
\text { gizi complete feed dan silase } \\
\text { bagi ternak? }\end{array}$ & $0 \%$ & $100 \%$ \\
\hline $\begin{array}{l}\text { Pernah membuat complete } \\
\text { feed dan silase sebelumnya? }\end{array}$ & $2 \%$ & $98 \%$ \\
\hline
\end{tabular}

Setelah menyampaikan materi penyuluhan, kelompok mitra yang sebelumnya tidak tahu menjadi lebih tahu atau bertambah wawasannya.

Pada saat dilakukan sesi diskusi dan tanya jawab, respon kelompok mitra sangat antusias ditunjukkan dengan keaktifan dalam bertanya terkait materi yang telah disajikan.

Pada saat kegiatan penyuluhan juga dapat diketahui bahwa mayoritas masyarakat peternak di desa Sidorejo ternyata mempunyai kebiasaan membuang atau membakar limbah hasil pertaniannya padahal limbah tersebut bisa dimanfaatkan agar dapat bernilai tambah.

Semakin bertambah pengetahuan, pemahaman dan kesadaran peternak kelompok mitra akan manfaat pengolahan limbah pertanian menjadi pakan ternak dan bertekad untuk mengaplikasikannya secara mandiri maupun kelompok.

Sebanyak 4 orang peternak dari kelompok mitra yang sudah dapat mempraktekkan secara langsung mengolah limbah pertanian 
menjadi pakan fermentasi untuk ternak secara mandiri.

$\begin{array}{ll}\text { Gambar 1. } & \begin{array}{l}\text { Dokumentasi Kegiatan } \\ \text { Penyuluhan. }\end{array}\end{array}$

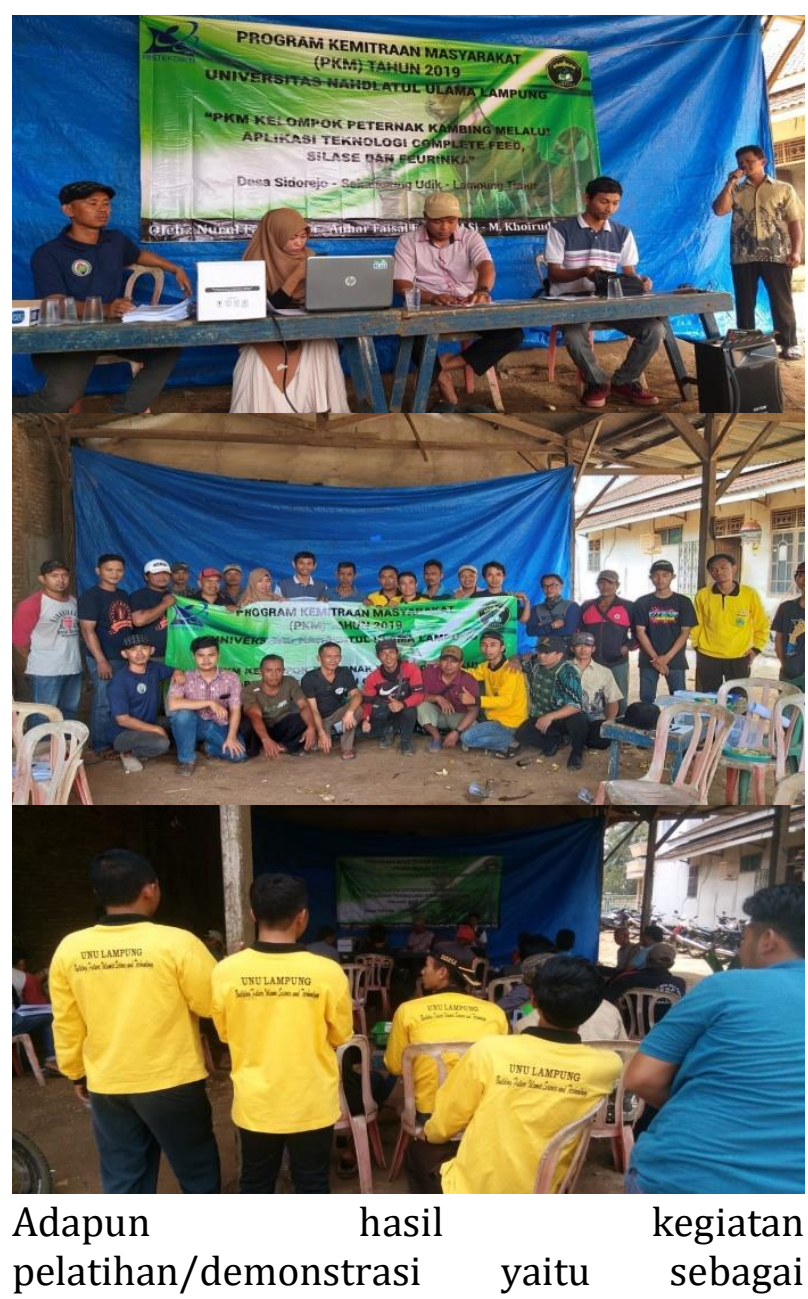

berikut :

Kegiatan diawali dengan mempersiapkan alat dan bahan untuk membuat complete feed dan silase. Pelaksanaan kegiatan pembuatan pakan tersebut dilakukan dengan diskusi terlebih dahulu mengenai pengenalan beberapa jenis bahan yang digunakan, manfaat masing-masing bahan, bahan tambahan yang dibutuhkan, dan masing-masing cara membuat complete feed dan silase serta perbedaan masing-masing kedua jenis teknologi pakan tersebut.

Bahan utama pembuatan Complete feed yaitu berbahan dasar limbah tanaman jagung yang merupakan suatu permasalahan pada daerah mitra karena jumlahnya yang melimpah, sehingga untuk mengatasi masalah tersebut maka diperkenalkan sentuhan teknologi untuk mengolah dan mengawetkan limbah tersebut menjadi pakan yang bergizi tinggi dan tentunya dapat meningkatkan penyediaan pakan ternak secara kontinyu dengan penambahan dedak, onggok, bungkil sawit, bungkil kedelai, CGF, garam, mineral, urea, molases dan susu kefir sebagai starternya.

Bahan utama pembuatan silase yaitu berbahan dasar limbah tanaman singkong yang juga merupakan permasalahan di daerah mitra karena jumlahnya yang melimpah dan tidak dimanfaatkan. Limbah tanaman singkong tersebut kemudian ditambahkan dedak, molases dan juga susu kefir sebagai starternya.

Selama kegiatan demonstrasi/pelatihan berlangsung, kelompok mitra cukup aktif dan antusias sehingga sangat mendukung kelancaran kegiatan selain itu mampu memahami dengan baik setiap prosedur dalam pembuatan pakan tersebut.

Adapun diakhir kegiatan dilakukan evaluasi kegiatan dengan mengadakan posttest. Pertanyaan yang diajukan sama dengan pertanyaan saat pretest. Hal ini dilakukan untuk mengetahui untuk mengetahui sejauh mana pemahaman peternak mitra terkait materi penyuluhan dan pelatihan yang telah dilaksankan. Hasil posttest disajikan pada tabel 2 berikut :

Tabel 2. Hasil Posttest

\begin{tabular}{|l|c|c|}
\hline \multicolumn{1}{|c|}{ Pertanyaan } & Ya & Tidak \\
\hline $\begin{array}{l}\text { Mengetahui tentang jenis } \\
\text { ternak kambing pedaging } \\
\text { dan penghasil susu di } \\
\text { Indonesia? }\end{array}$ & $100 \%$ & $0 \%$ \\
\hline $\begin{array}{l}\text { Mengetahui menejemen } \\
\text { yang baik dalam } \\
\text { memelihara kambing? }\end{array}$ & $100 \%$ & $0 \%$ \\
\hline $\begin{array}{l}\text { Mengetahui tentang tanda- } \\
\text { tanda ternak birahi/estrus? }\end{array}$ & $98 \%$ & $2 \%$ \\
\hline $\begin{array}{l}\text { Mengetahui } \\
\text { penanganan/pemeliharaan }\end{array}$ & $100 \%$ & $0 \%$ \\
\hline
\end{tabular}




\begin{tabular}{|l|c|c|}
\hline $\begin{array}{l}\text { anak kambing yang } \\
\text { berjumlah lebih dari } 2 \\
\text { ekor? }\end{array}$ & $100 \%$ & $0 \%$ \\
\hline $\begin{array}{l}\text { Mengetahui tentang } \\
\text { pengolahan limbah } \\
\text { tanaman singkong dan } \\
\text { limbah tanaman jagung } \\
\text { menjadi pakan bergizi? }\end{array}$ & $100 \%$ & $0 \%$ \\
\hline $\begin{array}{l}\text { Mengetahui tentang } \\
\text { teknologi complete feed dan } \\
\text { silase? }\end{array}$ & & \\
\hline $\begin{array}{l}\text { Mengetahui tentang cara } \\
\text { pembuatan complete feed? }\end{array}$ & $100 \%$ & $0 \%$ \\
\hline $\begin{array}{l}\text { Mengetahui tentang cara } \\
\text { membuat silase? }\end{array}$ & $100 \%$ & $0 \%$ \\
\hline $\begin{array}{l}\text { Mengetahui tentang } \\
\text { manfaat gizi complete feed } \\
\text { dan silase bagi ternak? } \\
\text { seed dan silase }\end{array}$ & $100 \%$ & $0 \%$ \\
\hline $\begin{array}{l}\text { Pernah membuat complete } \\
\text { Bemyar }\end{array}$ & $100 \%$ & $0 \%$ \\
\hline
\end{tabular}

Berdasarkan hasil posttest menunjukkan bahwa kegiatan pengabadian kepada masyarakat mengenai "PKM Kelompok Peternak Kambing Melalui Aplikasi Teknologi Complete Feed dan Silase di Desa Sidorejo Kecamatan Sekampung Udik" mampu meningkatkan wawasan, pemahaman dan keterampilan peternak mitra dalam mengolah limbah tanaman singkong dan tanaman jagung menjadi pakan yang bergizi dan berkualitas timggi sekaligus dapat disimpan lama untuk persediaan pada saat musim kemarau tiba. Dengan begitu, harapan kedepan peternak mitra sudah dapat menerapkan kegiatan tersebut secara mandiri ataupun berkelompok.

Disamping itu, dari kegiatan pengabdian ini peternak mitra mendapatkan banyak manfaat untuk mendukung keberlanjutan kegiatan usaha mereka dengan dibekali beberapa informasi mengenai jenis-jenis kambing yang potensial untuk dikembangkan, bagaimana manajemen pemeliharaan kambing yang baik hingga jenis-jenis pakan berkualitas dan bergizi tinggi dari bahan dasar limbah pertanian yang tentu saja kedepannya dapat diterapkan untuk persiapan menghadapi musim kemarau.

\section{KESIMPULAN}

Berdasarkan hasil dari kegiatan pengabdian ini, maka dapat disimpulkan bahwa pengetahuan dan pemahaman peternak mitra di Desa Sidorejo Kecamatan Sekampung Udik mengenai teknologi pengolahan pakan menjadi bertambah dan meningkat. Kegiatan pengabdian ini berjalan dengan lancar dan mendapatkan respon yang positif dari seluruh anggota mitra ditandai dengan antusias yang tinggi dengan aktif bertanya dan berdiskusi pada saat pelaksanaan kegiatan. Disamping itu, pada saat demonstrasi pembuatan complete feed dan silase seluruh peserta kelompok sangat antusias dengan ikut serta aktif dalam kegiatan pelatihan/demonstrasi, selain itu mampu memahami dengan baik setiap prosedur dalam pembuatan pakan tersebut.

Mengingat besarnya manfaat kegiatan pengabdian pada masyarakat ini, maka selanjutnya perlu diadakan pelatihan serupa pada masyarakat di wilayah lainnya, perlu dilakukan monitoring program setelah kegiatan pengabdian ini sehingga peternak khususnya di Desa Sidorejo Kecamatan Sekampung Udik Lampung Timur, benarbenar dapat mempraktekkan pembuatan complete feed dan silase secara mandiri hingga mampu menyediakan cadangan pakan saat musim kemarau.

\section{UCAPAN TERIMAKASIH}

Ucapan terima kasih disampaikan kepada DRPM Ristekdikti yang telah mendanai 
kegiatan pengabdian ini melalui Program Hibah Pengabdian Masyarakat dengan Skema Program Kemitraan Masyarakat (PKM) tahun anggaran 2019.

\section{DAFTAR PUSTAKA}

Hardianto, R., D.E. Wahyono, C. Anam, Suryanto, G. Kartono dan S.R.Soemarsono. 2002. Kajian Teknologi Pakan Lengkap (Complete feed) sebagai peluang agribisnis bernilai komersial di pedesaan. Makalah Seminar dan Ekspose Teknologi Spesifik Lokasi. Agustus 2002. Badan Litbang Pertanian, Jakarta. Howard, R.L; Abotsi, E; Jansen van Rensburg El and Howard, S. 2003. African Journal of Biotecnology . Vol. 2 (12) : 602619

Hartadi, H. 1991. Ilmu Makanan Ternak Dasar. Cetakan Kelima Gajah Mada University Press Yogyakarta.
Nusi, M., R.Utomo dan Soeparno. 2011. Pengaruh penggunaan tongkol jagung dalam complete feed dan suplementasi undegraded protein terhadap pertambahan bobot badan dan kualitas daging pada Sapi Peranakan Ongole. Buletin Peternakan Vol. 35(3): 1-9

Syarifuddin. H., Ridwan M., dan Suryadi. 2015. Ibm Aplikasi Teknologi Feurinsa Menuju Peternakan Ramah Lingkungan. Jurnal Pengabdian pada Masyarakat. Vol. 3 (4) : 61-69

Thiasari, N., dan Setiyawan, A. I., 2016. Complete feed batang pisang terfermentasi dengan level protein berbeda terhadap kecernaan bahan kering, kecernaan bahan organik dan TDN secara in vitro. Jurnal Ilmu-Ilmu Peternakan 26 (2): 67 - 72. 